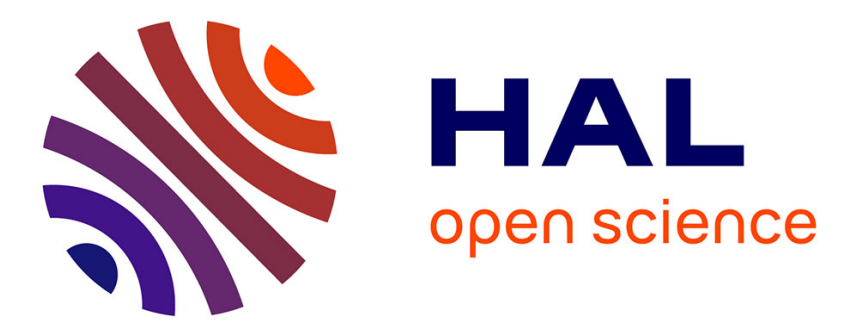

\title{
The pharmacokinetics of xylazine hydrochloride: an interspecific study.
}

\author{
Rafael Garcia Villar, P.L. Toutain, M. Alvinerie
}

\section{To cite this version:}

Rafael Garcia Villar, P.L. Toutain, M. Alvinerie. The pharmacokinetics of xylazine hydrochloride: an interspecific study.. Journal of Veterinary Pharmacology and Therapeutics, 1981, 4, pp.87-92. hal-02723514

\section{HAL Id: hal-02723514 \\ https://hal.inrae.fr/hal-02723514}

Submitted on 2 Jun 2020

HAL is a multi-disciplinary open access archive for the deposit and dissemination of scientific research documents, whether they are published or not. The documents may come from teaching and research institutions in France or abroad, or from public or private research centers.
L'archive ouverte pluridisciplinaire HAL, est destinée au dépôt et à la diffusion de documents scientifiques de niveau recherche, publiés ou non, émanant des établissements d'enseignement et de recherche français ou étrangers, des laboratoires publics ou privés.

\section{다(1)(2)}

Distributed under a Creative Commons Attribution - ShareAlikel 4.0 International 


\title{
The pharmacokinetics of xylazine hydrochloride: an interspecific study
}

\author{
R. GARGIA-VILLAR,P.L. TOUTAIN, M. ALVINERIE \\ \& Y. RUCKEBUSGH
}

Station de Pharmacologie-Toxicologie, 180 chemin de Tournefeuille, 31300 Toulouse, France

\begin{abstract}
Garcia-Villar, R., Toutain, P.L., Alvinerie, M. \& Ruckebusch, Y. The pharmacokinetics of xylazine hydrochloride. J. vet. Pharmacol. Therap. 4, 87-92.

The pharmacokinetic disposition of xylazine hydrochloride is described after both intravenous and intramuscular injection of a single dose, in four domestic species: horse, cattle, sheep and dog, by an original high performance liquid chromatographic technique. Remarkably small interspecific differences are reported. After intravenous administration, systemic half-life $\left(t_{1 / 2} \beta\right)$ ranged between $22 \mathrm{~min}$ (sheep) and $50 \mathrm{~min}$ (horse) while the distribution phase is transient with half-life $\left(t_{1 / 2 \alpha}\right)$ ranging from $1.2 \mathrm{~min}$ (cattle) to $5.9 \mathrm{~min}$ (horse). The peak level of drug concentration in the plasma is reached after $12-14 \mathrm{~min}$ in all the species studied following intramuscular administration. Xylazine bioavailability, as measured by the ratios of the areas under the intravenous and intramuscular plasma concentration versus time curves, ranged from $52 \%$ to $90 \%$ in $\operatorname{dog}, 17 \%$ to $73 \%$ in sheep and $40 \%$ to $48 \%$ in horse. The low dosage in cattle did not permit calculation. Kinetic data are correlated with clinical data and the origins of interspecific differences are discussed.
\end{abstract}

Professor P. L. Toutain, Pharmacologie-Toxicologie INRA, 180 chemin de Tournefeuille, 31300 Toulouse, France.

\section{INT RODUGTION}

Xylazine hydrochloride (Rompun, Bayer, Puteaux, France) is the generic name for 2(2.6 dimethylphenylamino)-4H-5.6 dihydro1.3 thiazine hydrochloride, a drug extensively used in veterinary practice for its potent sedative, analgesic and myorelaxant properties (Clarke \& Hall, 1969). In spite of numerous clinical studies, no extensive work in the pharmacokinetics of xylazine has been reported in domestic animals.

In rats, Duhm, Maul, Medenwald, Patzschke \& Wegner (1969) using radio-labelled xylazine,

0140-7785/81/0600-0087\$02.00

(c) 1981 Blackwell Scientific Publications found that after intravenous (i.v.) injection $(0.2-1.0 \mathrm{mg} / \mathrm{kg})$ the drug was rapidly distributed to different tissues and that $70 \%$ of the radio-activity was eliminated in urine with a half-life of about $2-3 \mathrm{~h}$, only $8 \%$ of the activity corresponding to the unchanged form of the drug.

In sneep, following intramuscular (i.m.) administration $(1.0 \mathrm{mg} / \mathrm{kg})$ Putter \& Sagner (1973) found that two-thirds of the dose was absorbed within $10 \mathrm{~min}$. In the urine of cattle, they reported that less than $1 \%$ unchanged xylazine was eliminated during the first $2 \mathrm{~h}$, with an apparent half-life of $40 \mathrm{~min}$. The peak excretion of metabolites occurred between 2 and $4 \mathrm{~h}$ after the administration of the drug, 
thus suggesting that xylazine is extensively metabolized, as has been reported to occur in rats. In the horse, Sams (1979) reported a half-life of $49 \mathrm{~min}$ for xylazine after an intravenous (i.v.) bolus injection, but only one horse was used and no details of the assay method were given.

The paucity of pharmacokinetic data in domestic animals is probably related to the lack of an appropriate analytical method. Recently, a rapid, sensitive and specific high performance liquid chromatography (HPLC) technique has been proposed by Alvinerie \& Toutain (1981) for an accurate evaluation of xylazine in biological fluids.

The aim of the present work was to determine the pharmacokinetics of xylazine hydrochloride, after both i.v. and i.m. administration, in four domestic species: horse, cattle, sheep and dog.

\section{MATERIALS AND METHODS}

\section{Animals}

Healthy and sexually-mature horses, cattle, sheep and dogs were used. The number of animals, weights and diets are listed in Table I.

\section{Drug applications and blood sampling}

Xylazine hydrochloride was administered intravenously into the right jugular vein in horse, cattle and sheep and into the cephalic vein in dog. Intramuscular injections were made into the deep muscles of the neck in horses and cattle, and into the gluteus muscle in sheep and dogs. The dosage regimen was that generally recommended and is shown in Table I.

A catheter was inserted into the left jugular vein $2 \mathrm{~h}$ before the administration of the drug in all the species except the dog. In dogs, a polyvinyl catheter filled with heparinized saline was surgically implanted under general thiopentone anesthesia $(20 \mathrm{mg} / \mathrm{kg}) 1$ week before starting the experiment.

Blood samples $(5 \mathrm{ml})$ were collected into dry heparinized tubes. 'l'he same schedule was used for the four species and the two routes of administration viz: control and 1, 2, 4, 8, $16,30,60$ and $120 \mathrm{~min}$ after drug injection. After each sampling the catheter was rinsed with heparinized $0.9 \%$ saline solution. Blood was centrifuged and the plasma fraction was frozen at $-20^{\circ} \mathrm{C}$ until assay. In sheep, urine was collected every $10 \mathrm{~min}$ after i.v. administration.

\section{Assays}

'The plasma concentration of xylazine hydrochloride was measured by an original HPLC method already published. The main steps of the procedure were as follows: after addition of $1 \mathrm{~g}$ of internal standard (doxapram) and $1 \mathrm{ml}$ of $0.05 \mathrm{M}$ borax buffer solution to aliquots of plasma $(0.5 \mathrm{ml})$, the sample was vortexed for $5 \mathrm{sec}$ and then shaken with 10 $\mathrm{ml}$ of chloroform for $10 \mathrm{~min}$; after centrifugation at $11.400 \mathrm{~g}$ for $10 \mathrm{~min}$, the organic phase was isolated and evaporated at $70^{\circ} \mathrm{C}$ under a nitrogen gas stream. The evaporated extract was redissolved in $100 \mu$ of mobile phase $(2 \%$ glacial acetic acid in water, methanol, hep tane sulphonic acid; $55: 45: 0.2$; $\mathrm{v} / \mathrm{v} / \mathrm{v}$ ). The entire sample was injected in the HPLC system (Model 6000 A, Waters Assoc., Milfordt, Mass, U.S.A.). The ultraviolet (u.v.) detector (GM 770, Schoeffel Instruments) was operated at a wavelength of $225 \mathrm{~nm}$; this assay procedure is sensitive enough to estimate blood concentrations of xylazine down to $10 \mathrm{ng}$ per $\mathrm{ml}$.

TABLE I. Doses and experimental conditions

\begin{tabular}{|c|c|c|c|c|}
\hline & Animals $(n)$ & Weight $(\mathrm{kg})$ & Diet & Dosage $(\mathrm{mg} / \mathrm{kg})^{*}$ \\
\hline Horse & 4 & $415-550$ & $\begin{array}{l}\text { Pelleted food } 7 \mathrm{~kg} / \text { day } \\
\text { Straw and water ad libitum }\end{array}$ & 0.6 \\
\hline Cattle & 4 & $240-440$ & Hay and water ad libitum & 0.2 \\
\hline Sheep & 6 & $42-65$ & Hay and water ad libitum & 1.0 \\
\hline Dog & 4 & $14-24$ & Canned food ad libitum & 1.4 \\
\hline
\end{tabular}

*Dosage expressed as xylazine-base. 


\section{Mathematical and statistical methods}

Pharmacokinetic analysis was performed by least square regression analysis using a programmed Hewlett Packard $41 \mathrm{C}$ calculator, according to the generally accepted methods (Baggot, 1977).

\section{RESULTS}

\section{Intravenous administration studies}

Figure 1 shows the semi-logarithmic plot of plasma xylazine concentration versus time, after i.v. dosage in the four species. Decay of xylazine concentration is biphasic and the pharmacokinetic analysis of data is performed by applying the appropriate biexponential equation for a two-compartment open model

$$
C_{p}^{t}=\mathrm{A} \cdot \mathrm{e}^{-\alpha t}+\mathrm{B} \cdot \mathrm{e}^{-\beta t}
$$

where $C_{p}^{t}$ is the plasma xylazine concentration $(\mu \mathrm{g} / \mathrm{ml})$ at time $t(\mathrm{~min}) ; \mathrm{A}, \mathrm{B}$ are the zero-time intercepts of plasma drug concentration obtained by extrapolation of the distribution and elimination curves; $\alpha, \beta$ are the hybrid rate constants of a two-compartment open model. The other calculated parameters included transfer rate constants for distribution and elimination $\left(k_{12}, k_{21}, k_{\mathrm{el}}\right)$, apparent volume of distribution $\left(V_{d(\text { area })}\right)$ and body clearance
$\left(C l_{B}\right)$. The values of these different parameters are shown in 'Table II. In all species, half-time of distribution was very short $(1.2-5.9 \mathrm{~min})$, half time of elimination varied from 23 to 50 $\mathrm{min}$ and the volumes of distribution were large $(2-2.7 \mathrm{l} / \mathrm{kg})$; in the urine of sheep, xylazine was not detectable.

\section{Intramuscular administration studies}

Figure 2 shows the semi-logarithmic plot of plasma xylazine concentration versus time after i.m. dosage in the four species. Levels of drug peaked rapidly and then declined exponentially over the next $150 \mathrm{~min}$, except for cattle, in which xylazine was not detected in the plasma. These data were well fitted by a one-compartment open model with a transient absorption (invasion) phase followed by an elimination phase. The Bateman function can be applied.

$$
C_{p}^{t}=\frac{\mathrm{k}_{\mathrm{a}} B_{0}}{\mathrm{k}_{\mathrm{a}}-\mathrm{k}_{\mathrm{el}}}\left(e^{-\mathrm{k}_{\mathrm{el}} t}-e^{-\mathrm{k}_{\mathrm{a}} t}\right)
$$

where $C_{p}^{t}$ is the plasma xylazine concentration $(\mu \mathrm{g} / \mathrm{ml})$ at time $t(\mathrm{~min}) ; \mathrm{k}_{\mathrm{a}}$ is the rate constant for absorption; $\mathrm{k}_{\mathrm{el}}$ is the rate constant for elimination and $B_{0}$ is the zero-time concentration intercept of plasma drug concentration versus time curve.

Table III gives the values of $k_{a}$ and $k_{e l}$, $C_{\max }$ (maximal plasma concentration), $T_{\max }$

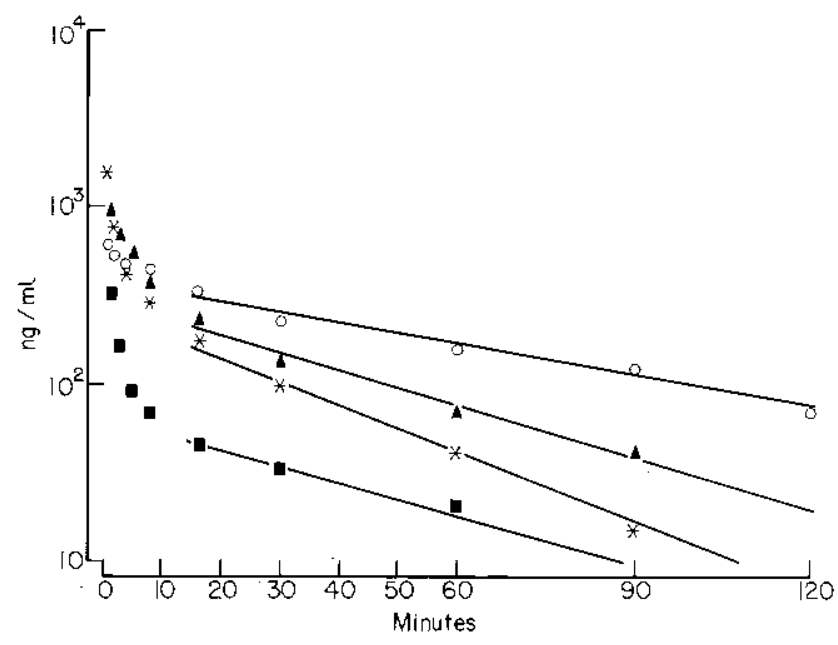

FIG. 1. Semi-logarithmic plot of average xylazine plasma concentration versus time in the four species studied after intravenous injection of a single dose: only the elimination phase (regression line) of the disposition curve is drawn. (O) Horse $0.6 \mathrm{mg} . \mathrm{kg}^{-1} ;(\Delta)$ dog $1.4 \mathrm{mg} . \mathrm{kg}^{-1} ;(*)$ sheep $1.0 \mathrm{mg} . \mathrm{kg}^{-1}$; (匚) cattle $0.2 \mathrm{mg}^{-1} \mathrm{~kg}^{-1}$. 
(time corresponding to $C_{\max }$ ); the latter two parameters were calculated from appropriate equations. Half-time of absorption was short in the three species $(2.7-5.5 \mathrm{~min})$; the maximal concentration was obtained in $13 \mathrm{~min}$.

\section{Bioavailability}

I'he calculation of systemic bioavailability is based on the ratio of total area under curves obtained after i.v. and i.m. administration of equal doses. 'l'he areas were determined by the trapezoidal method. The extrapolation of the curve to infinity was obtained from $C_{p}{ }^{t l} . \beta$, where $C_{p}{ }^{t l}$ was the last measured concentrations of drug and $\beta$ the overall elimination rate constant. 'The bioavailability varied less in the horse (extreme range of $40 \%$ to $48 \%$ ) than in the sheep (extreme range $17 \%$ to $73 \%$ ) and the $\operatorname{dog}(52 \%$ to $90 \%)$. ('Table III). It was impossible to measure bioavailability in cattle as xylazine was not detected in the plasma.

\section{DISCUSSION}

After an intravenous administration, the differences noticed between the four species under study are remarkably small. After a rapid distribution, with a half-life comprised between 1.2 and $6 \mathrm{~min}$, the apparent volume of distribution is large $(1.9-2.7$ litres $/ \mathrm{kg})$ suggesting that xylazine, as expected for a weak organic base, diffuses extensively. The rapid elimination of xylazine is probably related to an intense metabolism rather than to a rapid renal excretion of unchanged xylazine. This hypothesis is supported by the lack of significant amounts of intact drug found in urine collected every $10 \mathrm{~min}$ in sheep. Moreover, preliminary results from three anaesthetized rabbits indicate that no modifications of pharmacokinetics of xylazine occur after occlusion of the two renal arteries. No attempts were made in order to identify the different catabolites of xylazine, but according to Duhm et al. (1969) using radio-labelled xylazine in rats, this drug undergoes a rapid metabolism yielding about twenty end products. After intramuscular administration, absorption of xylazine is rapid with a halftime of absorption of 2.8-5.4 min. However, plasma concentrations are not detectable in cattle, a point which could be explained by the low dosage used for this very xylazinesensitive species.

The pharmacokinetic results obtained in the present experiment are in good agreement with clinical data in horses and dogs; by contrast the pharmacokinetic data are difficult to relate to the known clinical effects of xylazine in cattle.

TABLE II. Pharmacokinetic parameters of xylazine hydrochloride in the four studied species after intravenous injection of a single dose

\begin{tabular}{lcccc}
\hline \multicolumn{1}{c}{ Kinetic parameter } & $\begin{array}{c}\text { Horse } \\
(n=4)\end{array}$ & $\begin{array}{c}\text { Cattle } \\
(n=4)\end{array}$ & $\begin{array}{c}\text { Sheep } \\
(n=6)\end{array}$ & $\begin{array}{c}\text { Dog } \\
(n=4)\end{array}$ \\
\hline$C_{p}^{0}\left(\mu \mathrm{g} \cdot \mathrm{ml}^{-1}\right)$ & 0.598 & 1.050 & 1.551 & 1.382 \\
$\mathrm{~A}\left(\mu \mathrm{g} \cdot \mathrm{ml}^{-1}\right)$ & 0.217 & 0.990 & 1.298 & 1.072 \\
$\alpha\left(\mathrm{min}^{-1}\right)$ & 0.116 & 0.575 & 0.367 & 0.270 \\
$t_{1 / 2 \alpha}(\mathrm{min})$ & 5.970 & 1.205 & 1.889 & 2.567 \\
$\mathrm{~B}\left(\mu \mathrm{g} \cdot \mathrm{ml}^{-1}\right)$ & 0.381 & 0.065 & 0.259 & 0.306 \\
$\beta\left(\mathrm{min}^{-1}\right)$ & 0.014 & 0.022 & 0.030 & 0.023 \\
$t_{1 / 2 \beta}\left(\mathrm{min}^{2}\right)$ & 49.51 & 36.48 & 23.105 & 30.130 \\
$V_{d(\mathrm{area})}\left(1 . \mathrm{kg}^{-1}\right)$ & 2.456 & 1.944 & 2.740 & 2.517 \\
$C l_{B}\left(\mathrm{ml}^{-1} \mathrm{~kg}^{-1} \cdot \mathrm{min}^{-1}\right)$ & 21 & 42 & 83 & 81 \\
$\mathrm{k}_{12}\left(\mathrm{~min}^{-1}\right)$ & 0.030 & 0.318 & 0.183 & 0.135 \\
$\mathrm{k}_{21}\left(\mathrm{~min}^{-1}\right)$ & 0.079 & 0.057 & 0.086 & 0.078 \\
$\mathrm{k}_{\mathrm{el}}\left(\mathrm{min}^{-1}\right)$ & 0.021 & 0.022 & 0.128 & 0.080 \\
\hline
\end{tabular}




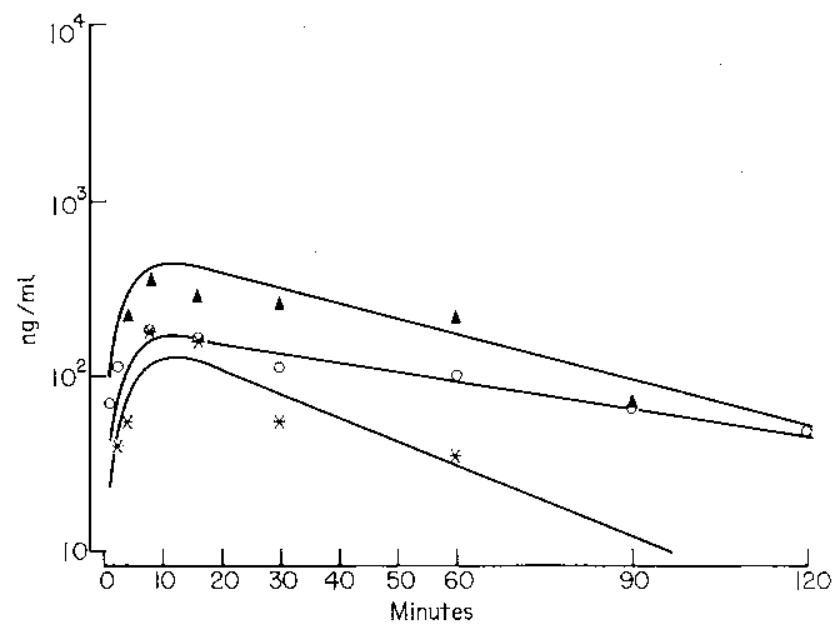

FIG. 2. Semi-logarithmic plot of average xylazine plasma concentration versus time in the four species studied after intramuscular injection of a single dose: invasion and elimination phases are drawn. ( $\Delta$ ) $\operatorname{Dog} 1,4 \mathrm{mg} \mathrm{kg}^{-1}$; (O) horse $0.6 \mathrm{mg} \cdot \mathrm{kg}^{-1} ;(*)$ sheep $1.0 \mathrm{mg} \cdot \mathrm{kg}^{-1}$.

In the horse, following intravenous administration of xylazine, maximum sedation occurs within 4-8 min after injection (Hoffman, 1974; McCashin \& Gabel, 1971) a delay which is comparable with the half-time of distribution $(6 \mathrm{~min})$. In the same way, duration of deep sedation after intravenous administration $(15-20 \mathrm{~min})$ and recovery $(30-60 \mathrm{~min})$ from time of injection (Clarke \& Hall, 1969) are comparable with the half-time of plasma concentration $(50 \mathrm{~min})$. After intramuscular administration, sedation is usually evident by $10 \mathrm{~min}$ and reaches its maximum effect by 15 min (McCashin \& Gabel, 1971) a delay which corresponds to the time necessary to obtain the maximal plasma concentration (13 $\mathrm{min}$ ). Doses recommended by the manufacturer for the i.m. route are double the doses recommended for the i.v, route. This recommendation based on clinical data is well explained by the incomplete absorption of xylazine since the bioavailability is about $45 \%$. 'Thus, in horses, clinical and pharmacokinetic data are well correlated, suggesting that xylazine itself, and not a metabolite, is the active drug.

In the dog, recommended dosage is higher than in other species $(1-3 \mathrm{mg} / \mathrm{kg}$ i.v. $)$. Ac-

TABLE III. Pharmacokinetic parameters and bioavailability of xylazine hydrochloride in the four species after intramuscular injection of a single dose

\begin{tabular}{lcccc}
\hline & $\begin{array}{c}\text { Horse } \\
(n=4)\end{array}$ & $\begin{array}{c}\text { Cattle } \\
(n=4)\end{array}$ & $\begin{array}{c}\text { Sheep } \\
(n=6)\end{array}$ & $\begin{array}{c}\text { Dog } \\
(n=4)\end{array}$ \\
\hline $\mathrm{k}_{\mathrm{a}}\left(\mathrm{min}^{-1}\right)$ & 0.251 & ND* & 0.127 & 0.201 \\
$t_{1 / 2 k a}(\min )$ & 2.720 & ND & 5.450 & 3.441 \\
$\mathrm{k}_{\mathrm{el}}=\beta\left(\min ^{-1}\right)$ & 0.012 & $\mathrm{ND}$ & 0.031 & 0.020 \\
$t_{1 / 2 \beta}(\min )$ & 57.70 & $\mathrm{ND}$ & 22.36 & 34.65 \\
$T_{\max }(\min )$ & 12.92 & $\mathrm{ND}$ & 14.68 & 12.70 \\
$C_{\max }\left(\mu \mathrm{g}+\mathrm{ml}^{-1}\right)$ & 0.167 & $\mathrm{ND}$ & 0.129 & 0.432 \\
Bioavailability & & & & $73.9 \pm 17.89$ \\
mean $\pm \mathrm{SD}$ & $44.6 \pm 4.16$ & $\mathrm{ND}$ & $40.75 \pm 23.81$ & $52-90$ \\
Range & $40-48$ & & $17-73$ & \\
\hline
\end{tabular}

*ND, not determined (the assay method is not sensitive enough to evaluate xylazine plasma concentrations lower than $0.01 \mu \mathrm{g} \cdot \mathrm{ml}^{-1}$ ) 
cording to Newkirk \& Miles (1974), the time of onset of action is $3-5 \mathrm{~min}$ after i.v, administration and $10-15 \mathrm{~min}$ after i.m. injection and the period of analgesia is relatively short (about 15-30 min); these data are compatible with our kinetic parameters.

In sheep, the dosage regimen is higher than in cattle and bioavailability determination is possible. After i.m. dosage, absorption is rapid and rather similar to results reported by Putter \& Sagner (1973) who estimated that twothirds of the dose was absorbed within $10 \mathrm{~min}$ from the injection site. 'The extent of absorption is about $40 \%$, a fact which explains the higher dosage recommended for i.m. injection in this species.

Gattle are very sensitive to xylazine and dose rates that produce deep sedation and analgesia are one-tenth those required to produce the same effects in horses (Hopkins, 1972). This difference cannot be explained in terms of plasma concentration of xylazine since plasma concentration is six to seven times lower in cattle than in the horse for a similar behavioural effect. Moreover, some sustained effects of xylazine in cattle are not explained in terms of plasma kinetics. The short half-time of xylazine in cattle $(36 \mathrm{~min})$ contrasts with duration of hyperthermia: $18 \mathrm{~h}$ (Young, 1979), hyperglycemia: $24 \mathrm{~h}$ (Eichner, Prior \& Kuasnicka, 1979), and prostration following high dosage: $36 \mathrm{~h}$ (Clarke \& Hall, 1969). Finally, after i.m. administration, we were not able to detect xylazine in bovine plasma in spite of evident sedative and analgesic effects. The lack of correlation between xylazine concentration and the different pharmacological responses may suggest that cattle rapidly produce one or several long-acting metabolites. The special sensitivity of this species to xylazine is thus more probably related to the drug metabolism than to a special reactivity to xylazine.

Finally, the HPLC assay of xylazine allows an accurate assessment of drug plasma concentration and the estimation of the different kinetic parameters. The results explain some clinical data and suggest hypotheses concerning interspecific variability in sensitivity to xylazine.

\section{ACKNOWLEDGMENTS}

The authors gratefully acknowledge the technical assistance of Mrs Soual and Mr Caussette. This work was supported by a grant of the Animal Pathology Department of the Institut National de la Recherche Agronomique (France).

\section{REFERENGES}

Alvinerie, M. \& Toutain, P.L. (1980) Determination of xylazine in plasma using high performance liquid chromatography. Journal of Chromatography. (In press.)

Baggot, J.D. (1977) Principles of drug disposition in domestic animals. In 'The Basis of Veterinary Clinical Pharmacology. W. B. Saunders Co., Philadelphia.

Clarke, K.W. \& Hall, L.W. (1969) Xylazine. A new sedative for horses and cattle. Veterinary Record, $85,512-517$.

Duhm, B., Maul, W., Medenwald, M., Patzschke, K. \& Wagner, L.A. (1969) Unfersuchungen mit radiaktiv markierten Bay Va 1470 An Ratten. Berliner und Münchener Tierärztliche wochenschrift, 82, 104-109.

Eichner, R.D., Prior, R.L. \& Kuasnicka, W.G. (1979) Xylazine induced hyperglycemia in beef cattle. American Joumal of veterinary Research, 40, 127-129.

Hoffman, P.E. (1974) Clinical evaluation of xylazine as a chemical restraining agent, sedative and analgesic in horses. Journal of American veterinary Medicine Association, 164, 42-45.

Hopkins, T.J. (1972) 'The clinical pharmacology of xylazine in cattle. Australian veterinary Journal, $48,109-112$.

McCashin, F.B. \& Gabel, A.A. (1971) Rompun. A new sedative with analgesic properties, Proceedings of 17th Annual Convention of the American Association of Equine Practitioners, 111-116.

Newkirk, H.L. \& Miles, D.G. (1974) Xylazine as a sedative analgesic for dogs and cats. Modern veterinary Practice, 55, 677-680.

Putter, J. \& Sagner, G. (1973) Chemical studies to detect residues of xylazine hydrochloride. Veterinary Medicine Reviews, 73/2, 145-159.

Sams, R. (1978) Pharmacokinetic and metabolite considerations as they apply to clinical pharmacology. In Equine pharmacology, Eds Powers, J.D. \& T.E., pp. 17-33. American Association of Equine Practitioners, Golden, Colorado.

Thurmon, J.G., Nelson, D.R., Hartsfield, S.M. \& Rumore, C.A. (1978) Effect of xylazine hydrochloride in urine in cattle. Australian veterinary Journal, 54, 178-180.

Young, P.C. (1979) The effect of xylazine on the body temperature of cattle. Australian veterinary Journal, 55,442 . 